\title{
About the Artist: Natalie Robertson
}

$\mathrm{N}_{\mathrm{a}}$

atalie Robertson (Ngāti Porou, Clann Dhònnchaidh) is an Aotearoa/New Zealand photographer, video artist, and senior lecturer at Auckland University of Technology whose work has been exhibited at the Musée du Quai Branly (Paris), Museo Nacional de las Culturas (Mexico City), Musée de la Civilisation (Québec), and Cuba Casa de la Cultura de Tulum (Havana), as well as in Germany, China, Brazil, the United Kingdom, the United States, New Caledonia, Australia, and Aotearoa/New Zealand. Whether docu-

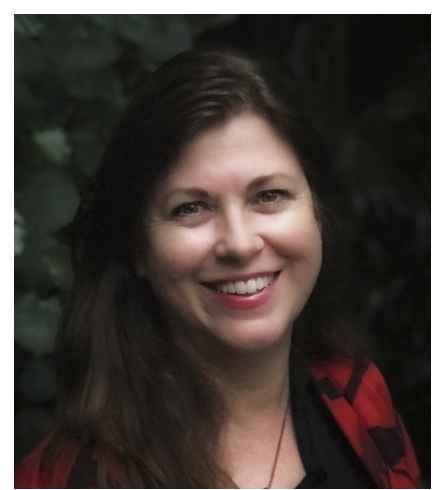

Photo by Moana Nepia menting the effects of modern agricultural practices on the natural environment, observing intimate rituals of care and communal responsibility, or tracing tribal pathways along rivers from aerial drone cameras, Robertson draws on both customary and contemporary ways of seeing and histories of storytelling that connect people to places and to one another. Robertson's work may also be understood in terms of what she describes as a "gap between what is real and what is imagined," as "the distance between what is now, and what will be" in "the wing-beat of a piwakawaka, a fantail." Moments captured photographically in this way reveal as much about creative potential and imagination as they do about social concern. Robertson's photographic contributions for A Whakapapa of Tradition: One Hundred Years of Ngāti Porou Carving, I830-I930, written by Ngarino Ellis (2016), won the Judith Binney Best First Book Award for Illustrated Non-Fiction at the 20I 7 Ockham New Zealand Book Awards. In early 20I9, she represented Aotearoa/New Zealand at the second Honolulu Biennial (https://www .honolulubiennial.org/honolulubiennial20I9).

MOANA NEPIA

The art featured in this issue can be viewed in full color in the online versions. 


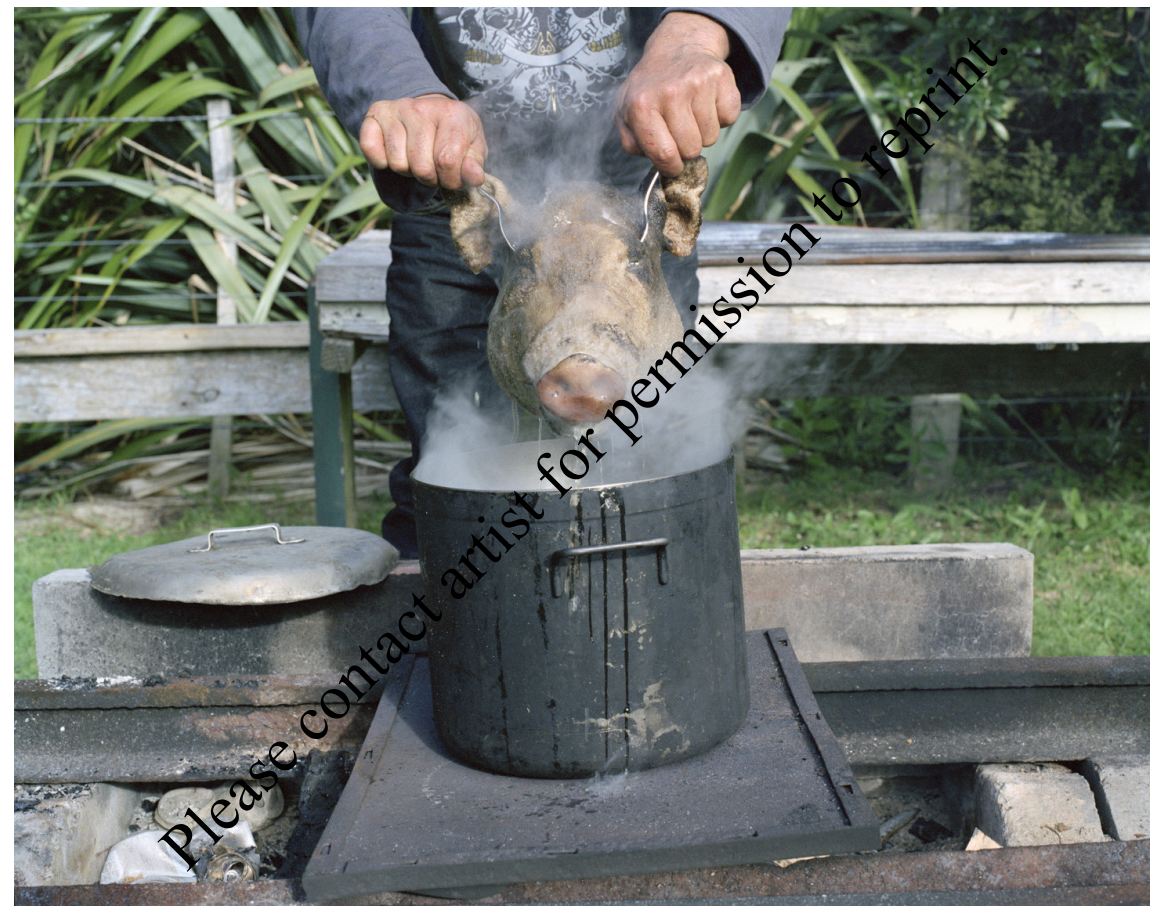

Boiled Pig Head, Te Rimu, Tikapa, by Natalie Robertson, 20 I 2. Inkjet print on Ilford Gold Silk Paper, $22 \times 28$ inches.

In October I769, Captain James Cook and his Endeavour crew reached Aotearoa/New Zealand. Within the first hour of landfall at Turanga-nui-a-Kiwa (now the site of Gisborne city) crew members killed Te Maro, a local Ngāti Oneone rangatira (chief). By the end of the next day, several more Māori were shot dead. Two hundred and fifty years later, these events still loom large in the minds of local Māori. As in Hawai' $i$, where he was eventually killed, Cook is remembered by many for the tragic consequences of such interactions and the devastating impacts of colonization that followed rather than for his application of scientific methods to exploration. Robertson's Boiled Pig Head takes on heightened meaning in this light. Feral pigs nicknamed "Captain Cookers," first introduced by early European visitors, are now hunted by Māori; boiled with kūmara (sweet potato), puha (sow thistle), and watercress; or cooked in hāngi (earth ovens), especially on large festive occasions. 


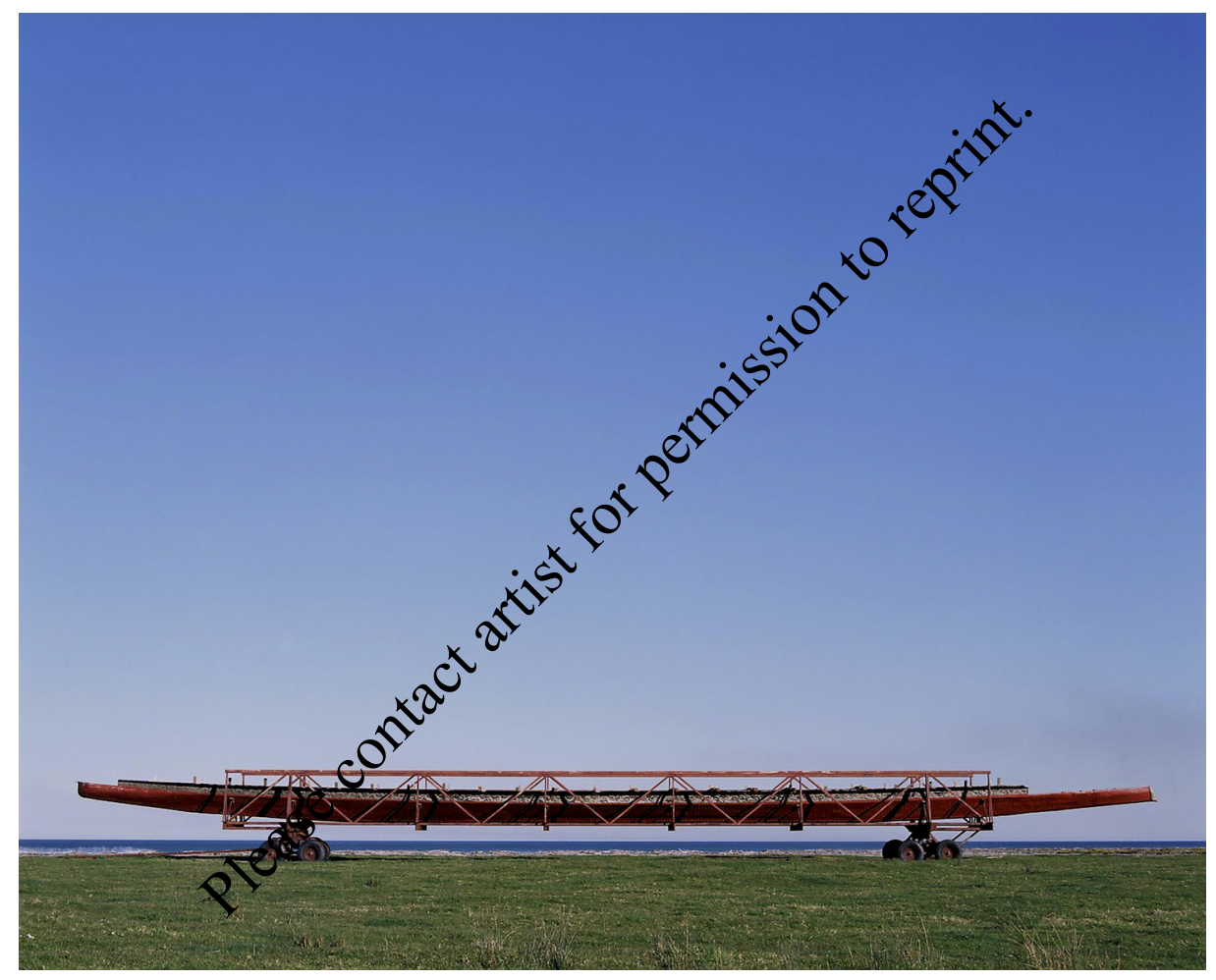

Nukutaimemeha, Rangitukia, by Natalie Robertson, 20 I I.

Inkjet print on Ilford Gold Silk Paper, $22 \times 28$ inches.

For the people of Ngāti Porou, from Aotearoa/New Zealand's East Coast region, Nukutaimemeha is the name of the waka from which Maui fished up Te Ika-a-Maui (North Island). They believe it remains in fossilized form on Mt Hikurangi, the tallest mountain in this region and the first point of land in Aotearoa/New Zealand to see the sun each day. The waka in this image, bearing the full name Te Aio o Nukutaimemeha, was carved by Greg Matahi Whakataka-Brightwell, who is renowned for helping to rejuvenate the art of oceangoing waka building in Aotearoa/New Zealand and introducing waka ama (outrigger canoe) racing to the country's sporting scene. Commissioned to commemorate the I 5 oth anniversary of the signing of the Treaty of Waitangi, Nukutaimemeha measures approximately 45 meters long and was completed in I999. Never launched, Nukutaimemeha has rested in a paddock at the mouth of the Waiapu River for many years. Plans to move it to Mt Hikurangi were announced in 2019. 


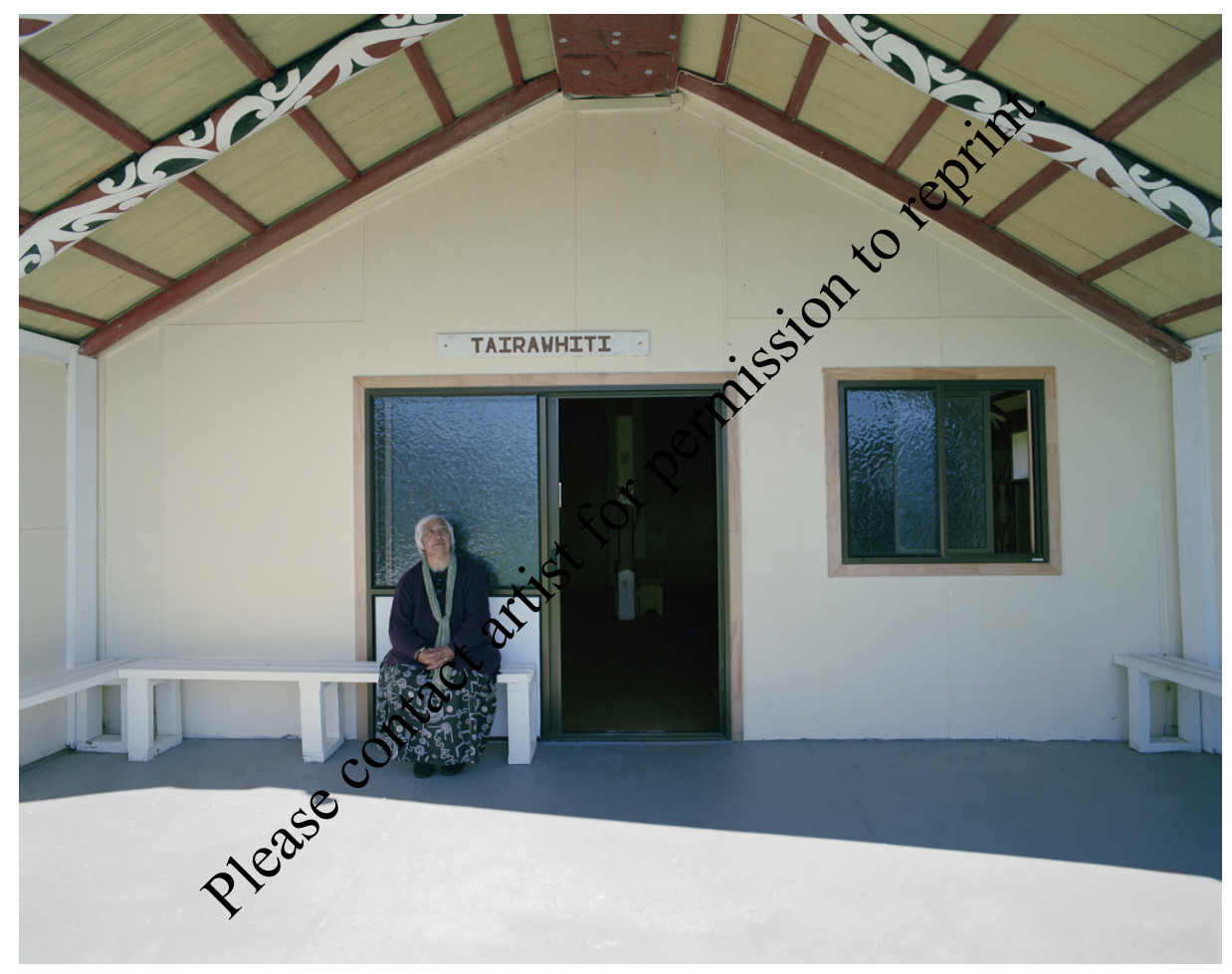

Keri Kaa on the Tairawhiti Mahau, Hinepare Marae, Rangitukia, by Natalie Robertson, 2012.

Inkjet print on Ilford Gold Silk Paper, $22 \times 28$ inches.

Local rangatira (chiefs) and kaumatua (elders) living close to, or returning to, their ancestral marae keep connections between the past and present alive for their families and wider communities through their presence and leadership. In this image, Hohi Ngapera Te Moana Keri Kaa sits in the shade of the mahau (porch) in front of her family's wharenui (meeting house), next to her family home at Rangitukia. Of Ngāti Kahungunu, Ngāti Rongomaiwahine, and Ngāti Porou descent, she comes from an esteemed line of orators and spiritual and religious leaders. She is a writer, retired educator, and mentor to many Māori academics and artists, including Robertson. For her advocacy of Te Reo Māori (the Māori language) and Māori arts, she has been made a Companion of the Order of Merit of New Zealand and received a Queen's Service medal, as well as awards from Creative New Zealand, Te Waka Toi, and Women in Film and Television New Zealand. 


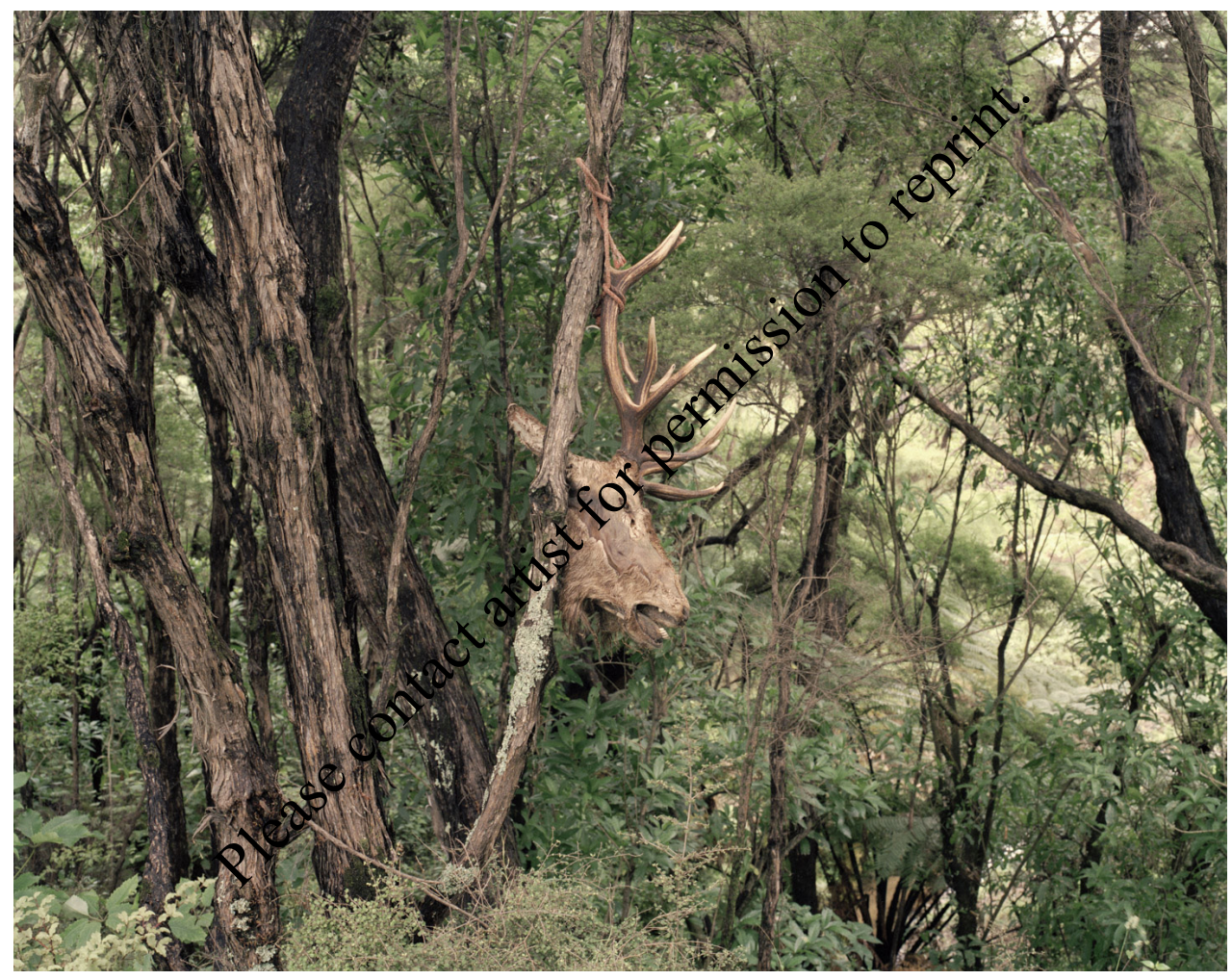

Deer Head, Te Rimu, Tikapa, by Natalie Robertson, 2013.

Inkjet print on Ilford Gold Silk Paper, $22 \times 28$ inches.

Red deer from Scotland and England, first introduced to Aotearoa/New Zealand in I $85 \mathrm{I}$, quickly became widespread throughout the country. Like the wapiti (elk) from Yellowstone National Park that were gifted to Aotearoa/ New Zealand by US President Theodore Roosevelt in I905 and like other introduced deer species from Asia, possums from Australia, goats, pigs, and rabbits, they faced no natural predators in their new antipodean home, apart from man. Selective foraging has had devastating effects on native forests and vegetation, and this has led to large-scale erosion in places. Governmentsponsored eradication programs have had mixed success. While still hunted for their meat and for sport and farmed for lucrative markets in venison and health products, deer remain noxious pests. 


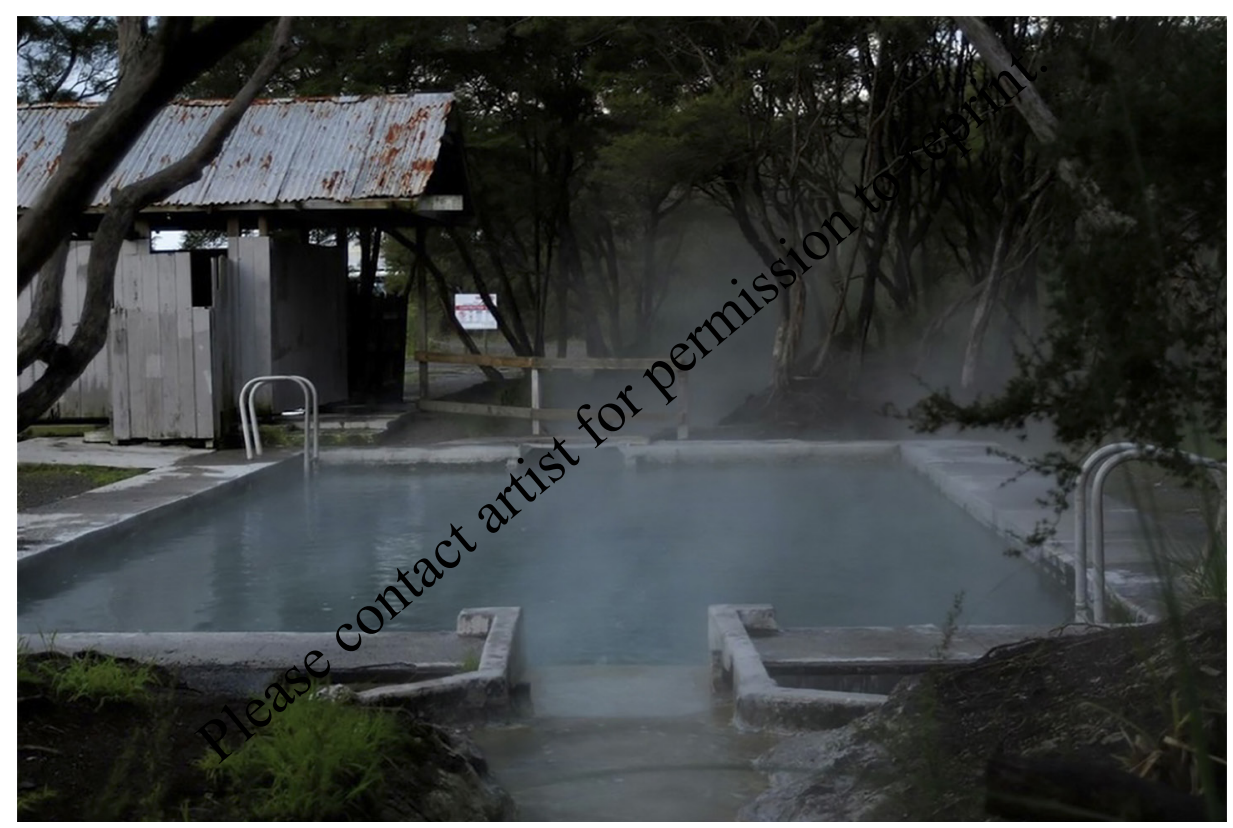

Savages Hotpools, Onepu, by Natalie Robertson, 2008.

Inkjet print on Ilford Gold Silk Paper, $22 \times 28$ inches.

In a 2006 Australian Centre for the Moving Image conference presentation on digital storytelling, Robertson described her project Uncle Tasman: The Trembling Current that Scars the Earth as "a visual narrative of volcanic and geothermal activity with Māori cosmology and the environmental impacts of the local pulp and paper industry." The project focused on Kawerau, the town where she was born and the site of the Tasman Paper and Pulp Mill, which was referred to as "Uncle Tasman" for its significance as the major employer for the local community. After years of spewing dioxins into the air and into streams that feed pools such as the one at Onepu depicted in this image, the mill eventually updated its bleaching processes and has reduced toxic emissions. 


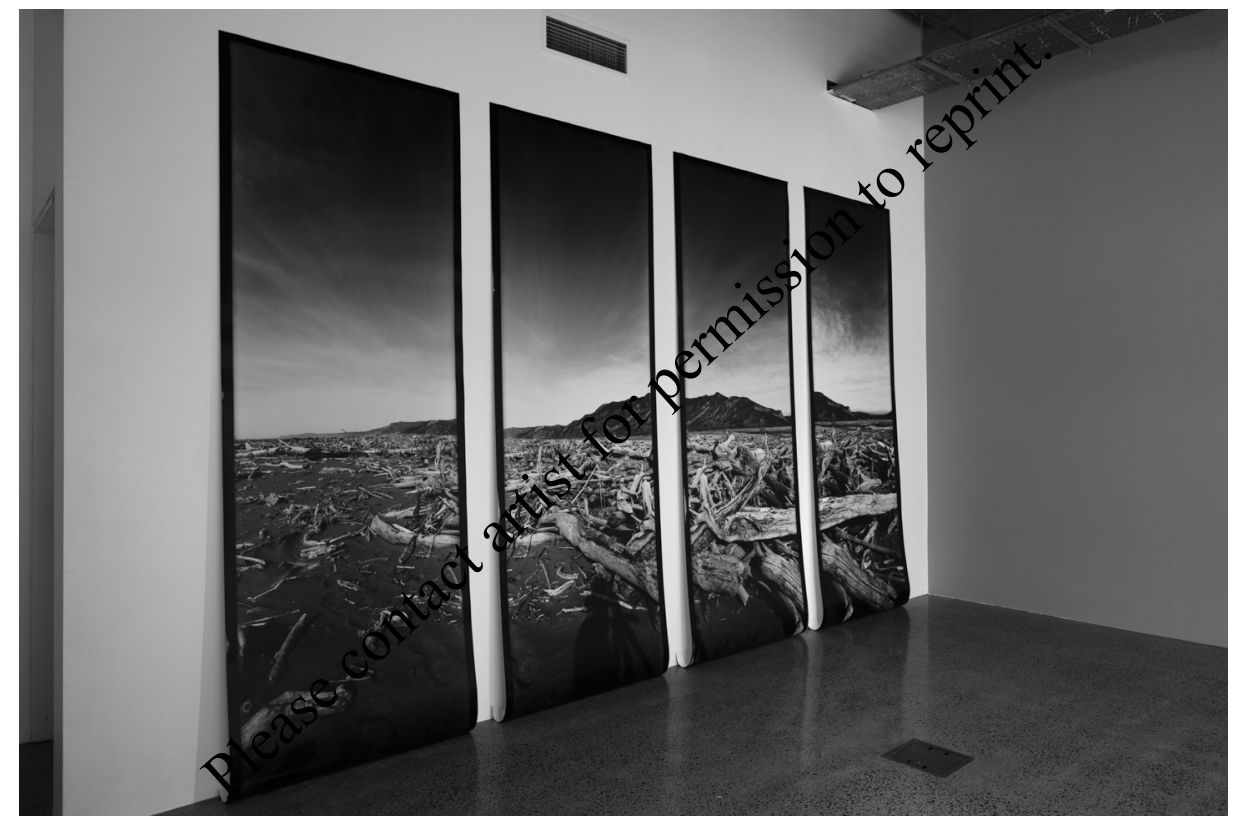

Pohautea I-4, by Natalie Robertson, 2015.

Inkjet print on Ilford Gold Silk Paper, $3.25 \mathrm{~m}$ X I.2 m each.

In this photographic installation of a horizontal landscape strewn with intertangled debris washed down from the Waiapu River, out to sea, and back onto local beaches, multiple vertical panels gesture toward the scale of human intervention in the local ecology. Seven years after the devastating March I988 Cyclone Bola, beaches were still piled high with timber from native trees. Similar environmental impacts along the East Coast followed back-to-back Cyclones Debbie and Cook in 2017. A sudden downpour in 2018 caused the Uawa River to flood, resulting in severe debris mobilization and disruption to local infrastructure and beaches around Tolaga Bay. It remains to be seen whether any new regulations or changes to forestry practices will prevent similar devastation in the future. Robertson's continued documentation of impacts in the Waiapu area, which have been neglected by media coverage, aims to make visible that which has escaped public attention. 


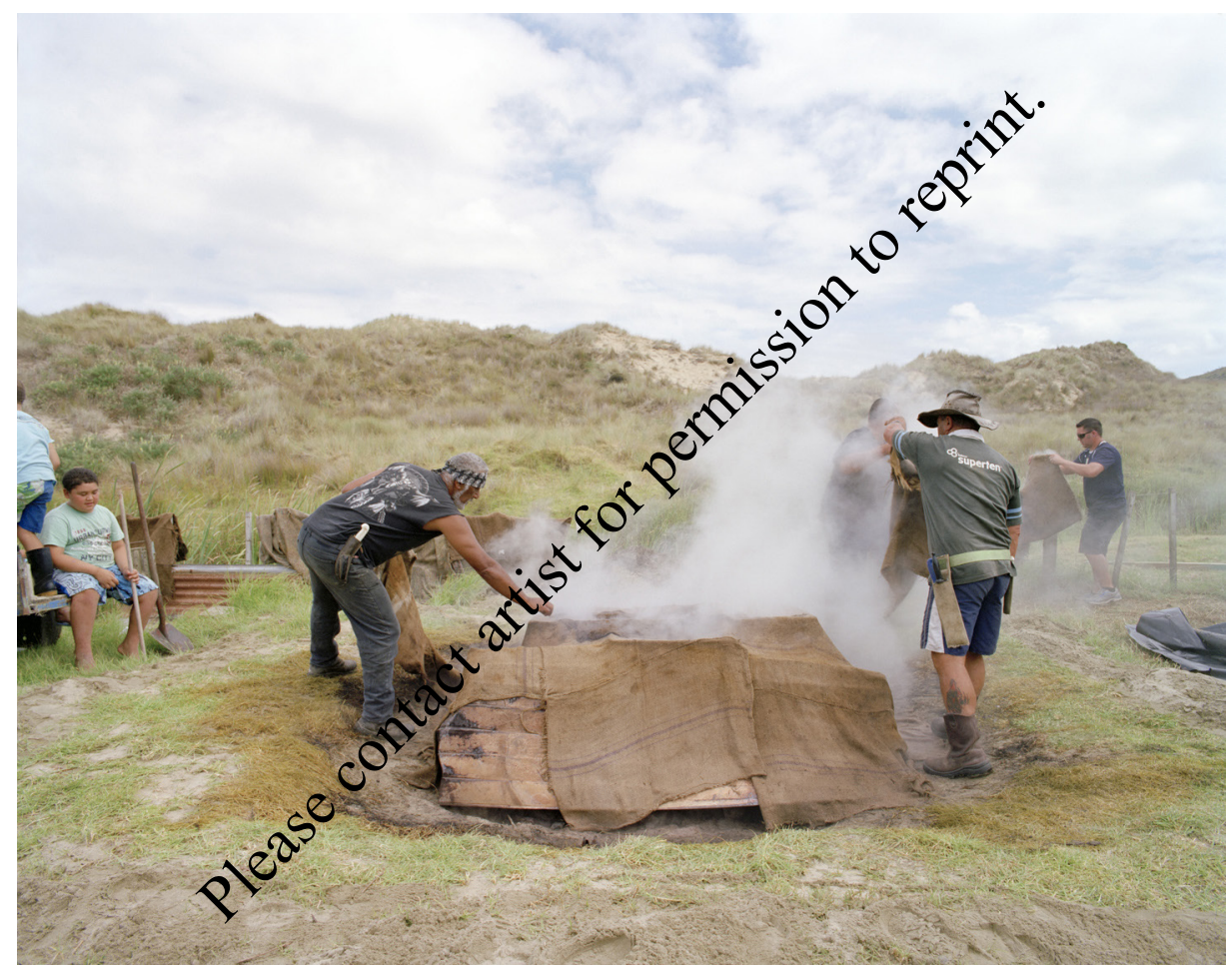

Opening the hangi. Te Wake unveiling. Matihetihe Marae.

During the tangihanga for Ralph Hotere, by Natalie Robertson, 2013.

Inkjet print on Ilford Gold Silk Paper, $22 \times 28$ inches.

Presented as part of a collection titled The Headlands Await Your

Coming, this image evokes the practices of ahi kaa roa (keeping the home fires burning) and manaakitanga (offering hospitality to visitors) through the provision of food-practices that proclaim and sustain mana whenua, or intergenerational authority, pride, and tribal connections to land. In the sweat of collaborative labor, and in the scent of rising steam from hāngi (earth ovens)—such as this one prepared for mourners of one of Aotearoa/New Zealand's most famous artists, Ralph Hotere, at Matihetihe Marae in Mitimiti-we also witness rituals of sustaining collective futures. 


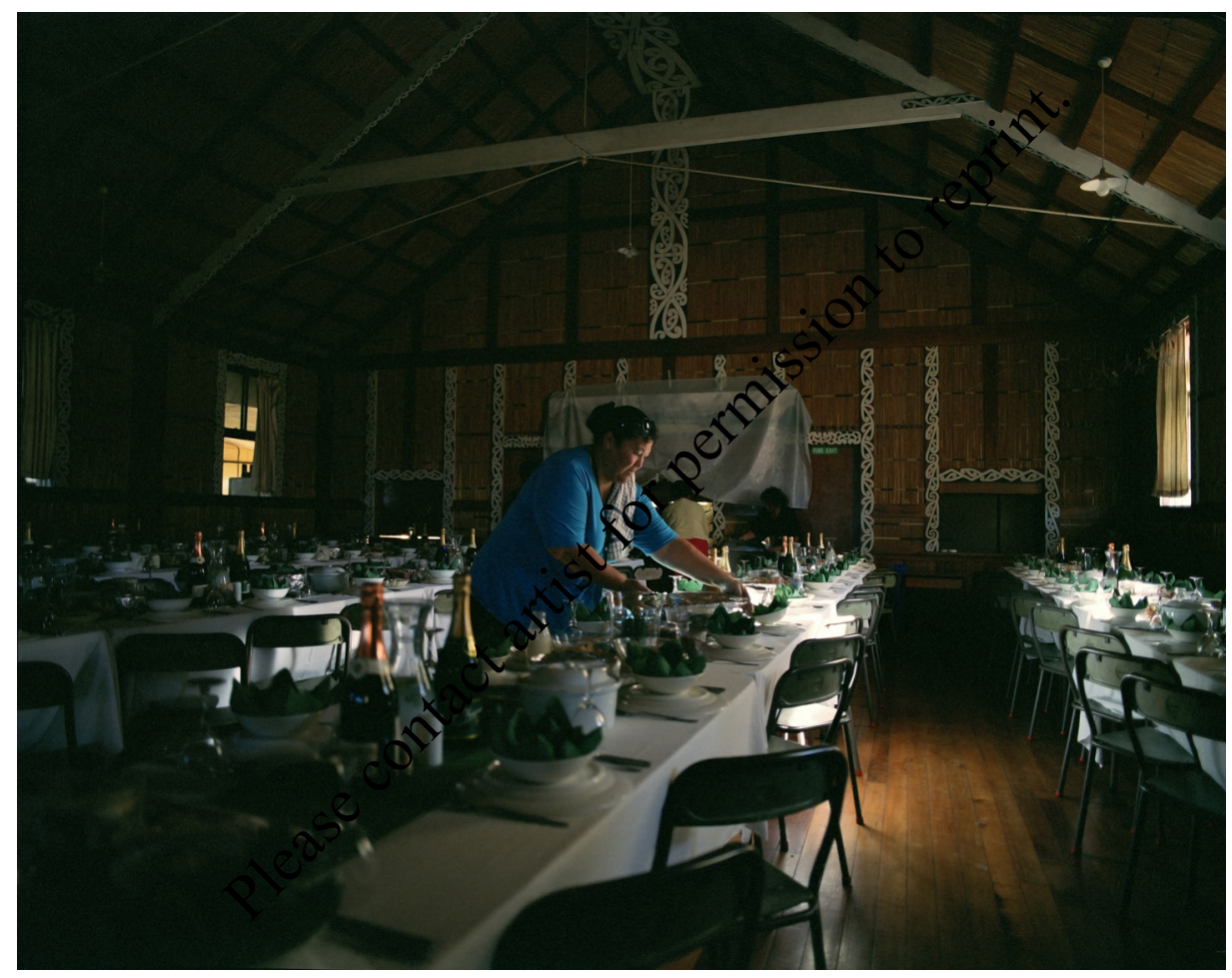

Diningroom, Lady Aribia wharekai, Waiomatatini Marae during Canon Morehu Te Maro's 8oth birthday celebrations, by Natalie Robertson, 20 IO.

Inkjet print on Ilford Gold Silk Paper, $22 \times 28$ inches.

Written accounts and early colonial illustrations of elaborate tiered displays of food and gifts prepared for visitors to Māori communities on important occasions are impressive records of gift-giving practices and how wealth could be assessed by how much a community could afford to give away. Contemporary hākari (feasts) in wharekai (dining rooms) on marae, such as this one at Waiomatatini, will similarly feature the best of local produce to represent the pride and well-being of a host community and the mana of honored guests. In softened light and during a quiet moment before the influx of visitors, one of the kai mahi (preparers of food) in this image adds a few finishing touches to each table. 


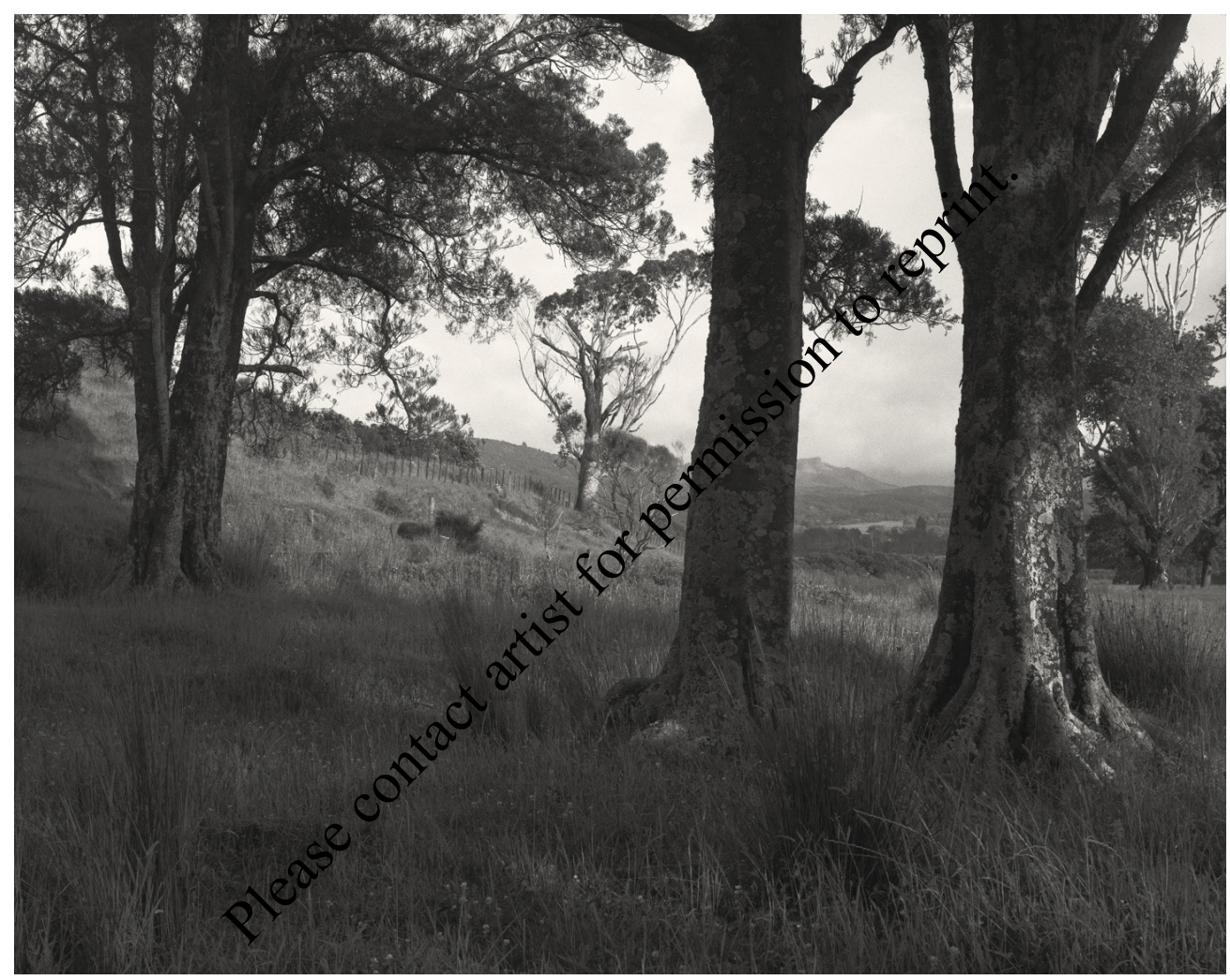

Te Mimi o Te Huinga Puna Wai and Kabikatea Trees, Tikapa-a-Hinekopeka III, by Natalie Robertson, 2019.

Digital dye-sublimated print on polyester, I I 8.5 X I 47.5 inches.

For the 2019 Honolulu Biennial, Robertson installed a series of black-and-white prints on dye-sublimated polyester of Kahikatea (Dacrycarpus dacrydioides) trees on Māori collectively owned land at Tikapa, Te Tairawhiti. Kahikatea are Aotearoa/New Zealand's tallest trees, growing to 50-65 meters (I64-2I3 feet), and were once the dominant species in the lowland swamp forests that are now almost extinct on Te Ika-a-Māui (North Island). About the health and well-being of her family's tribal homelands and waterways, she wrote:

Shall we plant the trees and flaxes and grasses that once grew thick and luscious on these lands providing materials we could weave and build from?

Today the Waiapu is neither thick with bush nor with people. As the bush was felled, the thick matted rain cape became threadbare.

It is time to mend the cape, to tend to the weft, to reweave.

We could take shelter together under the rain cape of Waiapu once again. 